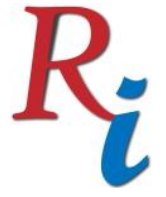

Asia Proceedings of Social Sciences

(APSS)

www.readersinsight.net/APSS

\title{
Early Warning Signals to Predict Islamic Bank Failure
}

\section{Zahid ur Rehman Khokher*}

Institute of Islamic Banking and Finance, International Islamic University

Malaysia

*Corrosponding author's Email: zaahid@gmail.com

Peer-review under responsibility of $4^{\text {th }}$ Asia International Conference 2018 editorial board (http://www.utm.my/asia/our-team/)

(C) 2018 Published by Readers Insight Publisher, lat 306 Savoy Residencia, Block 3 F11/1,44000 Islamabad. Pakistan,

info@readersinsight.net

This is an open access article under the CC BY-NC-ND license (http://creativecommons.org/licenses/by-nc-nd/4.0/). 


\section{Research High Iight s}

The paper empiricialy tests the use of various stability factors as early warning signals that can effectively predict the failure in Islamic banking institutions. These early warning signals enable the regulatory and supervisory authorities to take timely corrective action to safeguard the interest of fund providers such as depositors, investment account holders, creditors as well as other stakeholders. Using a 10-year panel data of 65 Islamic banks from 13 banking systems in the Middle East, North Africa, Asia and Europe, this study uses six stability indicators of CAMELS supervisory framework in a logistic model to see their effecitveness in predicting distress in Islamic banks. The model is then extended with the alternative capital are leverage ratios as well as macroeconomic variables in order to see whether simple leverage ratio offers better estimation results than the complex, risk weighted measures as debated by (Haldane, 2012).

\section{Research Objectives}

The objective of this paper is to study the effectivesss of various stability indicators such as capital adequacy, asset quality, profitability, management quality, liquidity, and risk sensitivity of assets to predict failure in Islamic banks. The predictive ability of regulatory capital ratio in signalling bank distress was questionned after it failed to perform effectively during the financial crisis (Mayes \& Stremmel, 2012). In response, the Basel Committee on Banking Supervision (BCBS) introduced a non-risk weighted leverage ratio (Admati, 2014; Hildebrand, 2008). Accordingly, this paper examines alternative capital and leverage ratios that can be reliably used as early warning signals to predict Islamic bank failure (Admati, 2014; Hildebrand, 2008). Due to differences in product structure and operational models, the underlying risk in Islamic banks has unique characterstics not found in conventional banks (Beck, Demirgüç-kunt, \& Merrouchec, 2013; Hasan \& Dridi, 2011; IMF, 2017). Similarly, increasing size and significance of Islamic banks in many emerging makets requires the availability of a suitable toolkit that can be used for monitoring the Islamic bank stability and which can send early warning signal in case of impending problems. This paper aims to suggest the signficant factors that can be effectively used for this purpose. 


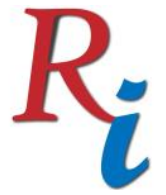

\section{Asia Proceedings of Social Sciences \\ (APSS) \\ www.readersinsight.net/APSS}

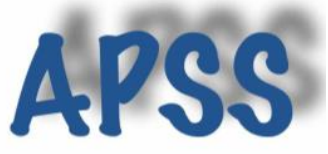

\section{Methodology}

The methodology used to adopt the ADDIE model of the stage Implementation and Evaluation. At the stage of implementation of the tests on 30 new Master Information Engineering Master's West Sumatra criteria of Informatics who teaches under 5 years old.

\section{Results}

The results confirm that regulatory capital adequacy ratio, management quality, liquidity and sensitivity to risk are significant in predicting distres in Islamic banks and all have expected signs. The coefficient of capital components is highest, showing its strong predictive power on the log-odds of Islamic bank distress. The Pseudo $\mathrm{R}^{2}$ is significant and goodness of fit parametes Hosmer-Lemeshow $\mathrm{Chi}^{2}$ and Pearson $\mathrm{Chi}^{2}$ are statistically significant at $5 \%$ and $1 \%$ levels respectively. Similarly, using the linear prediction technique with a cut-off point at $50 \%$ (Mayes \& Stremmel, 2012) classifies 97\% of distress in Islamic banks correctly predicted. The Pseudo $\mathrm{R}^{2}$ is highest when market leverage is used as capital indicator followed by Tier 1 capital and tangible common equity ratios. In all three cases, Pseudo $\mathrm{R}^{2}$ is higher than the base model where Basel capital adequacy ratio is considered as capital ratio. These three capital indicators are all significant and negatively signed as expected. For other indicators, liquidity and sensitivity to risk are significant. Another significant finding of this result is that Basel leverage ratio is not significant, which is in line with (Haldane, 2012). For macroeconomic variables, current account and GDP growth are statistically significant and have negative effect on Islamic bank distress.

\section{Findings}

The findings of this paper show that most of the standard stability indicators used in CAMELS framework are relevant for studying disterss in Islamic banking institutions. Most importantly, risk weighted capital ratios such as regulatory capital ratio, Tier 1 ratio and tangible common equity ratio are more relevant for Islamic banks than the use of newly introduced, non-risk weighted Base IIII leverage ratio. Liquidity factor is also quite 


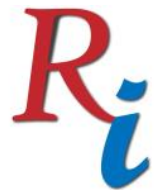

\section{Asia Proceedings of Social Sciences \\ (APSS) \\ www.readersinsight.net/APSS}

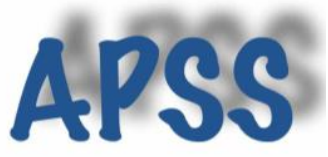

significant. The paper also shows the relevance of sensitivity to risk factor as well as use of market based leverage indicator in using as an early warning indicator for distress in Islamic banks. Overall, the paper showed that CAMELS based primary model is quite significant and offers reliable and effective signals for distress in Islamic banks, even without adding additional macroeconomic variables.

\section{References}

Admati, A. R. (2014). The Compelling Case for Stronger and More Effective Leverage Regulation in Banking. The Journal of Legal Studies, 43(S2), S35-S61. http://doi.org//10.1086/677557

Aliyu, S., \& Yusof, R. M. (2017). A PANEL SURVIVAL ANALYSIS FOR ISLAMIC BANKS. International Journal of Economics, Management and Accounting, 2(August), 381-410.

Beck, T., Demirgüç-kunt, A., \& Merrouchec, O. (2013). Islamic vs . Conventional Banking Business Model, Efficiency and Stability. Journal of Banking \& Finance, 37(2), 433-447. http://doi.org/10.1016/j.jbankfin.2012.09.016

Buehler, K. S., J., C. M., \& Samandari, H. H. (2010). A better way to measure bank risk One. McKinsey on Finance.

Estrella, A., Park, S., \& Peristiani, S. (2000). Capital Ratios as Predictors of Bank Failure. Federal Reserve Bank of New York Economic Policy Review. New York.

Haldane, G. A. (Bank of E. (2012). The Dog and the Frisbee. In Federal Reserve Bank of Kansas City's 36th economic policy symposium Proceedings, "The Changing Policy Landscape" (p. 37). Jackson Hole, Wyoming. Retrieved from www.bankofengland.co.uk/publications/Pages/speeches/default.aspx

Hasan, M., \& Dridi, J. (2011). The Effects of the Global Crisis on Islamic and Conventional Banks: a Comparative Study. Journal of International Commerce, Economics and Policy, 163(02), 47 Pages. http://doi.org/10.1142/S1793993311000270

Hildebrand, P. M. (2008). Is Basel II Enough? The Benefits of a Leverage Ratio. In Financial Markets Group Lecture: London School of Economics (p. 14). London: London School of Economics. Retrieved from http://www.bis.org/review/r081216d.pdf

IMF. (2017). Ensuring Financial Stability in Countries with Islamic Banking.

Kellermann, K., \& Schlag, C.-H. (2013). Occupy risk weighting: how the minimum leverage ratio dominates capital requirements: A Swiss example. Journal of Financial Regulation and Compliance, 21(4), 353-372. http://doi.org/10.1108/JFRC-062012-0019

Khan, U. E. (2016). Bankruptcy Prediction for Financial Sector of Pakistan : Evaluation of Copyright () 2018 Authors. This is an open access article distributed under theCreative Commons Attribution License, The which permits unrestricted use, distribution, and reproduction in any medium, Provided the original work is properly cited. 


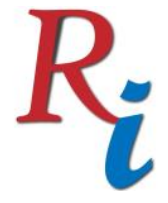

\section{Asia Proceedings of Social Sciences}

(APSS)

www.readersinsight.net/APSS

Logit and Discriminant Analysis Approaches. Pakistan Journal of Engineering Technology and Science, 6(2), 210-220.

Khokher, Z. ur R., \& Alhabshi, S. M. bin S. J. (2018). Capital Structure and Leverage Decisions in Publicly Listed Islamic Banks: What are Key Determinants? In Emerging Issues in Economics and Finance (pp. 1-22).

Mayes, D. G., \& Stremmel, H. (2012). The Effectiveness of Capital Adequacy Measures in Predicting Bank Distress. SUERF Working Paper. Retrieved from https://www.suerf.org/docx/s_dfbd282c18300fa0eccceea6c5fac41f_3991_suer f.pdf

Merrouche, A., Detragiache, E., \& Merrouche, O. (2010). Bank Capital: Lessons from the Financial Crisis (Wold Bank Policy Reseach Working Paper Series No. 5473). Wold Bank Policy Reseach Working Paper.

Pappas, V., Izzeldin, M., \& Fuertes, A. (2016). A Survival Analysis of Islamic and Conventional Banks. Journal of Financial Services Research, (Feb), 1-36. Retrieved from http://link.springer.com/article/10.1007/s10693-016-0239-0 